\title{
ANALISIS STUDI KELAYAKAN USAHA PUPUK ORGANIK BAGI KELOMPOK WANITA TANI DESA NAMBAAN DAN PENINGKATAN NILAI EKONOMI UD RSA KEDIRI
}

\author{
Lina Saptaria, S.Pd., M.M. \\ Universitas Islam Kadiri Kediri \\ Email : linauniskakediri@gmail.com \\ Samudi, SST., SP., M.Agr \\ Universitas Islam Kadiri Kediri \\ Email : samudimbah_moed@yahoo.co.id
}

\begin{abstract}
ABSTRAK
Limbah industri pengolahan cincau hitam UD RSA Kota Kediri dapat menjadi bahan baku pembuatan pupuk organik padat maupun cair. Pengelolaan usaha pembuatan pupuk organik dilaksanakan berdasarkan prinsip usaha kemitraan dengan Kelompok Wanita Tani Desa Nambaan. Penelitian ini bertujuan untuk mengetahui kelayakan usaha pupuk organik yang akan didirikan berdasarkan pendekatan aspek finansial dan aspek non finansial. Metodologi penelitian menggunakan pendekatan kuantitatif dan kualitatif. Metode penelitian berupa wawancara dan observasi. Analisis kelayakan finansial dilakukan dengan melakukan perhitungan nilai bersih sekarang (Net Present Value/NPV), Net benefit and Cost Ratio (Net B/C Ratio), dan masa pengembalian investasi (Payback Period). Analisis kelayakan non finansial dilakukan secara deskriptif dengan mengkaji lima aspek yaitu aspek pasar, aspek teknis, aspek manajemen, aspek hukum, dan aspek manfaat.

Hasil penelitian menunjukkan bahwa usaha pembuatan pupuk organik padat layak untuk dijalankan. Berdasarkan aspek finansial diketahui nilai NPV memiliki nilai positif atau NPV >0, maka usaha pupuk organik dinilai menguntungkan dan investasi usaha bisa dilaksanakan. Perhitungan rasio B/C memiliki nilai > 1, artinya usaha pupuk organik dinilai layak untuk dilaksanakan. Perhitungan masa pengembalian investasi cukup pendek yaitu 1 tahun 2 bulan. Secara non finansial usaha POP ini memenuhi standar kelayakan aspek pasar, aspek teknis, aspek manajemen, aspek hukum, dan aspek manfaat dan dapat menjadi bahan pengambilan keputusan bagi pihak UD RSA maupun pihak Kelompok Wanita Tani Desa Nambaan. Studi kelayakan usaha ini perlu dikembangkan dengan mengkaji sumber-sumber finansial selain modal sendiri dan menyempurnakan aspek-aspek non finansial yang belum dibahas dalam artikel ini.
\end{abstract}

Kata Kunci : Analisis Studi Kelayakan Usaha, Pupuk Organik, Kelompok Wanita Tani, Peningkatan Nilai Ekonomi

\section{ABSTRACT}

Waste processing industry of UD RSA black grass processing in Kediri City can be used as raw material for the manufacture of solid and liquid organic fertilizers. Management of the business of making organic fertilizer is carried out based on the principle of business partnership with the Nambaan Village Women Farmers Group. This study aims to determine the feasibility of organic fertilizer business that will be established based on the approach of financial aspects and non-financial aspects. The research methodology uses quantitative and qualitative approaches. Research methods in the form of interviews and observations. The financial feasibility analysis is carried out by calculating the Net Present Value (NPV), Net benefits and Cost Ratio (Net B / C Ratio), and the payback period for investment (Payback Period). Non-financial feasibility analysis is carried out descriptively by examining five aspects namely market aspects, technical aspects, management aspects, legal aspects, and aspects of benefits.

The results showed that the business of making solid organic fertilizer was feasible to run. Based on the financial aspect, it is known that the NPV value has a positive value or NPV> 0, so the organic fertilizer business is considered profitable and business investment can be carried out. The calculation of the $B / C$ ratio has a value of $>1$, meaning that the organic fertilizer business is considered feasible to carry out. Calculation of the investment return period is quite short, which is 1 year 2 months. Non-financially, this POP business meets the feasibility standard of market aspects, technical aspects, management aspects, legal aspects, and aspects of benefits and can be used as a material for decision making for UD RSA and the Nambaan Village Women Farmers Group. This business feasibility study needs to be developed by examining financial resources other than own capital and perfecting non-financial aspects that have not been discussed in this article.

Keywords: Analysis of Business Feasibility Study, Organic Fertilizer, Farmer Women Group, Economic Value Increase 


\section{PENDAHULUAN}

Dewasa ini sistem pertanian organik menjadi pilihan masyarakat petani karena semakin tingginya tingkat kesadaran untuk hidup sehat yang dimulai dari pilihan mengkonsumsi makanan organik. Meskipun demikian lahan pertanian organik di Indonesia baru mencapai 0,14 persen dari luas lahan sawah kurang lebih delapan juta hektar (Republika.co.id, 2017). Masih banyak petani Indonesia yang menerapkan sistem tanam konvensional dengan kebiasaan menggunakan pestisida dalam jumlah besar dan frekuensi pemberian pestisida yang terus menerus. Hal ini berdampak buruk bagi kesuburan tanah dan kesehatan masyarakat, oleh karena itu, sistem pertanian harus dirubah menjadi sistem yang ramah lingkungan dan menjamin kesehatan masyarakat. Solusi yang dicanangkan oleh pemerintah untuk menangani masalah ini adalah menggalakkan seribu desa dengan sistem tanam pertanian organik. Sistem pertanian organik adalah suatu sistem manajemen produksi yang holistik (menyeluruh) untuk meningkatkan dan mengembangkan kesehatan agroekosistem, termasuk keragaman hayati, siklus biologi, dan aktivitas biologi tanah. Pertanian organik menekankan penerapan praktik-praktik manajemen yang lebih mengutamakan penggunaan input dari limbah kegiatan budidaya di lahan dengan mempertimbangkan daya adaptasi terhadap keadaan atau kondisi setempat. Jika memungkinkan hal tersebut dapat dicapai dengan menggunakan budaya, metode biologi, dan mekanik, yang tidak menggunakan bahan sintesis untuk memenuhi kebutuhan khusus dalam sistem. (BSN, 2016)

Kelompok Wanita Tani (KWT) Desa Nambaan Kecamatan Ngasem Kabupaten Kediri telah merintis pertanian organik selama 5 tahun pada area pertanian seluas 500 ru. Konsep pertanian organik yang dilaksanakan adalah pertanian organik terpadu yang memadukan antara pertanian, peternakan dan perikanan dimana semua sarana produksi saling mengisi dan melengkapi kebutuhan aktifitas budidaya. Sistem ini diawali dengan penanaman komoditas hortikultura berupa buah-buahan dan sayursayuran seperti labu-labuan, sayur bayam, sawi, dan jagung manis. Pertanian organik memerlukan ketersediaan sumber daya berupa pupuk organik yang memadai. Kebutuhan akan pupuk organik KWT Desa Nambaan sebanyak $700 \mathrm{~kg}$ per musim tanam. Selama ini kebutuhan ini dipenuhi dengan cara membeli kepada pihak ketiga. Untuk meminimalisir biaya pembelian pupuk organik dalam memenuhi kebutuhan lahan setiap bulan, KWT Desa Nambaan telah melakukan usaha pembuatan pupuk organik secara mandiri.

Limbah industri yang dihasilkan oleh UD RSA Kota Kediri dapat dimanfaatkan sebagai bahan baku pembuatan pupuk organik. Kendala yang dihadapi oleh UD RSA dalam menangani limbah industrinya selama ini adalah belum adanya tenaga Sumber Daya Manusia yang mampu menangani dan mengelola limbah yang dihasilkan secara berkelanjutan. Untuk mengatasi masalah yang dihadapi, manajer UD RSA bermaksud bekerjasama dengan KWT Desa Nambaan untuk mendirikan usaha pembuatan pupuk organik. Adapun pertimbangan munculnya gagasan usaha secara kemitraan ini ada beberapa faktor antara lain : 1) KWT Desa Nambaan bersedia untuk mengolah dan mengkonsumsi pupuk organik yang akan dihasilkan melalui kegiatan penelitian, 2) KWT Desa Nambaan memiliki sarana dan prasarana yang memadai untuk menjalankan proses pembuatan pupuk organik, 3) UD RSA yang semula hanya membuang limbah industrinya di tempat pembuangan sampah akhir, menjadi lebih produktif dengan kegiatan usaha untuk mengolah limbah industrinya menjadi produk pupuk organik yang memiliki nilai ekonomi tinggi sehingga dapat menambah pendapatan usaha.

Industri pupuk organik di Indonesia sangat prospektif untuk dikembangkan karena semakin meningkatnya permintaan produk organik. Masyarakat mengenal produk organik sebagai makanan sehat yang aman dikonsumsi dan ramah lingkungan. Potensi pasar yang besar dapat mendukung keberhasilan usaha pupuk organik menjadi bisnis yang menguntungkan. Permintaan pupuk organik di wilayah Kota Kediri dan Kabupaten Kediri Tahun 2017 cukup besar mencapai 4.652.461 ton. Data kebutuhan pupuk organik di wilayah Kota dan Kabupaten Kediri adalah sebagai berikut. 
Tabel 1. Rencana Definitif Kebutuhan Kelompok (RDKK) Petroganik Wilayah Kota Kediri dan Kabupaten Kediri Tahun 2017

\begin{tabular}{|l|c|c|}
\hline \multicolumn{1}{|c|}{ Nama Instansi } & $\begin{array}{c}\text { Alokasi } \\
\text { (Ton) }\end{array}$ & $\begin{array}{c}\text { RDKK } \\
\text { (Ton) }\end{array}$ \\
\hline PT Diara & 8.669 & 17.922 \\
\hline CV Trisyan & 6.561 & 7.940 \\
\hline PD Canda Birawa & 2.815 & 6084.69 \\
\hline CV Target & 2.564 & 3.274 \\
\hline PT Lemsi & 2.087 & 7.818 .29 \\
\hline PT Eka Matra & 1.202 & 1.902 .8 \\
\hline $\begin{array}{l}\text { Total Kabupaten } \\
\text { Kediri }\end{array}$ & 26.170 & 46.334 .33 \\
\hline Total Kota Kediri & 1.202 & 1.902 .8 \\
\hline
\end{tabular}

Sumber data: Distributor Petrokimia Gresik, 2017

Sebelum wirausaha memulai menjalankan bisnis baru, wirausaha perlu melakukan penelitian untuk mengetahui apakah bisnis yang akan dilaksanakan akan menguntungkan atau tidak. Proyek investasi baik besar maupun kecil akan menghadapi tantangan berupa ketidakpastian yang mengandung resiko kerugian bagi wirausaha, oleh karena itu sangat penting melakukan analisis studi kelayakan usaha sebelum mengeluarkan investasi besar dalam sebuah proyek bisnis. Menurut Suryana (2000:139), studi kelayakan usaha adalah suatu penelitian tentang layak tidaknya suatu usaha dilaksanakan dengan menguntungkan secara kontinyu. Salah satu tujuan dilakukan studi kelayakan bisnis adalah untuk mencari jalan keluar agar dapat meminimalkan hambatan dan resiko yang mungkin timbul dimasa yang akan datang (Dr. Kasmir, 2016).

Proyek investasi yang akan dijalankan secara bekerjasama antara UD RSA dengan KWT Desa Nambaan memerlukan penelitian secara komprehensif sebelum proyek tersebut dijalankan. Analisis studi kelayakan bisnis pupuk organik bertujuan untuk mengetahui manfaat dan pengorbanan (benefit and cost) yang terjadi selama proyek investasi sedang berjalan. Untuk menentukan layak atau tidaknya suatu usaha harus dilihat dari berbagai aspek. Jumingan (2014), menjelaskan bahwa studi kelayakan usaha menilai keberhasilan suatu proyek dalam satu keseluruhan sehingga semua faktor harus dipertimbangkan dalam suatu analisis terpadu meliputi aspek teknis, aspek pasar dan pemasaran, aspek keuangan, aspek manajemen, aspek hukum, aspek manfaat proyek bagi ekonomi nasional. Setiap aspek dapat dikatakan layak apabila hasil analisis yang dilakukan telah memenuhi standar tertentu. Aspek yang kurang layak akan diberikan beberapa saran perbaikan sehingga memenuhi kriteria yang layak.

Penilaian setiap aspek kelayakan usaha memiliki arti penting sebagai dasar kegiatan perencanaan, pelaksanaan, evaluasi dan perumusan alternatif solusi serta pengambilan keputusan terkait penyelenggaraan aktivitas usaha di masa mendatang. Kriteria keberhasilan suatu usaha dapat dilihat dari manfaat investasi secara ekonomis (finansial), secara nasional, dan secara sosial. Manfaat ekonomis usaha berarti apakah usaha yang dijalankan cukup menguntungkan apabila dibandingkan dengan risiko usaha yang akan dihadapi. Manfaat usaha secara nasional berarti manfaat usaha bagi Negara secara makro. Manfaat sosial berarti manfaat usaha bagi masyarakat di sekitar lingkungan usaha.

\section{METODE PENELITIAN}

Penelitian ini dilaksanakan di KWT Desa Nambaan yang berlokasi di Desa Nambaan Kecamatan Ngasem Kabupaten Kediri Jawa Timur. Pemilihan tempat dilakukan secara sengaja (purposive) berdasarkan pertimbangan bahwa lokasi ini merupakan tempat proses produksi pupuk organik yang akan didirikan.

Pelaksanaan penelitian dan pengambilan data dilakukan pada bulan Maret hingga Juli 2018. Data yang dikumpulkan berupa data primer dan data sekunder. Data primer diperoleh melalui kegiatan wawancara dan observasi di lapangan.

Wawancara dilakukan dengan pihak manajemen pupuk organik yaitu ketua KWT Desa Nambaan dan Dinas Pertanian Kota dan Kabupaten Kediri. Metode wawancara didukung dengan format wawancara dan penyebaran instrument berupa daftar pertanyaan (kuesioner) kepada responden sasaran mengenai aspek kelayakan finansial dan non finansial. Data sekunder diperoleh melalui studi literatur berbagai buku, jurnal, skripsi, dan artikel yang terkait dengan topik penelitian. 
Metode observasi berarti peneliti melakukan pengamatan langsung mengenai seluruh proses kegiatan pembuatan pupuk organik mulai dari input, proses transformasi, dan output. Data kuantitatif yang diperoleh selama penelitian diolah dengan menggunakan program Microsoft Excel 2007. Sedangkan data kualitatif diolah dan diinterpretasikan secara deskriptif. Proses studi kelayakan usaha pupuk organik digambarkan dalam diagram berikut ini.

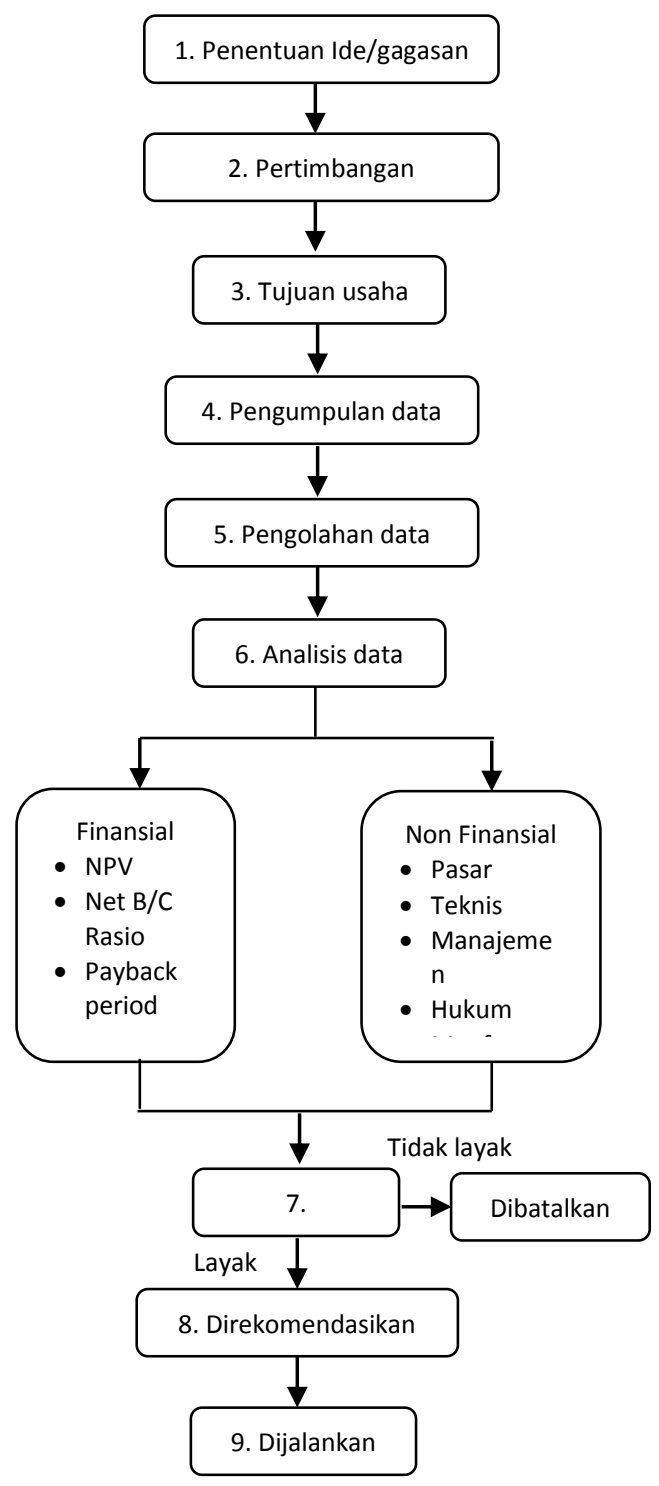

Gambar 1. Proses Studi Kelayakan Usaha Pupuk Organik

1) Tahap pertama, penentuan ide atau gagasan yaitu penemuan ide untuk merintis usaha baru atau mengembangkan usaha yang sudah ada dengan melakukan kegiatan studi literatur dan survei. Ide tersebut kemudian dirumuskan dan diidentifikasi.

2) Tahap kedua, pertimbangan alternatif yaitu mengkaji berbagai alternatif yang berhubungan dengan modal usaha, tenaga kerja, pengalaman, kemudahan, teknologi, bahan baku dan bahan penolong, bentuk produk yang akan dihasilkan, teknik

pembuatan produk, teknik pemasaran, pemilihan bentuk usaha.

3) Tahap ketiga, tujuan usaha yaitu perumusan visi dan misi usaha pupuk organik yang menjadi dasar perencanaan dan pengembangan tujuan usaha sesuai dengan perkembangan kebutuhan dan permintaan pasar.

4) Tahap keempat, pengumpulan data yaitu kegiatan mengelompokkan data baik data primer maupun data sekunder yang bermanfaat untuk kegiatan pengambilan keputusan manajemen usaha pupuk organik.

5) Tahap kelima, pengolahan data yaitu melakukan perhitungan secara matematis untuk mengolah data kelayakan usaha aspek finansial. Untuk mengolah data aspek non finansial, peneliti melakukan koordinasi dengan pihak narasumber dan merangkum hasil koordinasi secara deskriptif.

6) Tahap keenam, analisis data yaitu melakukan analisis aspek finansial dan aspek non finansial dari usaha pupuk organik. Analisis finansial adalah suatu analisis yang membandingkan antara biaya dan manfaat untuk menentukan apakah suatu usaha akan menguntungkan selama umur usaha. Analisis kelayakan finansial mengkaji kelayakan usaha berdasarkan perhitungan nilai bersih sekarang (Net Present Value/NPV), Net benefit and Cost Ratio (Net B/C Ratio), dan masa pengembalian investasi (Payback Period). Penjelasannya adalah sebagai berikut.

- Net Present Value (NPV) merupakan selisih antara pengeluaran dan pemasukan yang telah didiskon dengan menggunakan social opportunity cost of capital sebagai diskon factor. NPV merupakan arus kas yang diperkirakan pada masa yang akan datang dan didiskonkan pada saat ini. NPV juga 
dapat diartikan sebagai nilai sekarang dari arus kas yang ditimbulkan oleh investasi. Dengan menghitung NPV, suatu usaha menunjukkan manfaat bersih yang diterima usaha selama umur usaha pada tingkat suku bunga tertentu. Dalam menghitung NPV diperlukan data biaya investasi, biaya operasi, dan pemeliharaan, tingkat suku bunga yang relevan, perkiraan manfaat dari proyek yang direncanakan.

- Net Benefit Cost Ratio (Net B/C Rasio) menyatakan besarnya pengembalian terhadap setiap satu satuan biaya yang telah dikeluarkan selama umur usaha. Net B/C merupakan angka perbandingan antara present value dari net benefit yang positif dengan present value dari net benefit yang negatif.

- Payback Period

Payback Period atau tingkat pengembalian investasi adalah salah satu metode dalam menilai kelayakan suatu usaha yang digunakan untuk mengukur periode jangka waktu pengembalian modal. Semakin cepat modal itu dapat kembali, semakin baik suatu usaha untuk diusahakan karena modal yang kembali dapat dipakai untuk membiayai kegiatan lain. Suatu investasi

7) Tahap ketujuh, keputusan yaitu pengambilan keputusan setelah melakukan analisis kelayakan usaha secara finansial maupun non finansial. Keputusan yang diambil memiliki dua alternatif keputusan yaitu layak dan tidak layak. Jika usaha pupuk organik ini dinyatakan layak sesuai dengan kriteria yang telah ditetapkan, maka usaha pupuk organik bisa direkomendasikan dan dijalankan. Apabila hasil analisis menunjukkan usaha pupuk organik tidak layak maka proyek investasi dapat dibatalkan.

8) Tahap kedelapan, direkomendasikan yaitu memberikan rekomendasi kepada pihakpihak tertentu akan hasil studi kelayakan usaha pupuk organik. Peneliti dapat memberikan saran dan perbaikan yang diperlukan untuk menjalankan proyek investasi ini. dianggap layak apabila nilai PP lebih kecil dari umur usaha.

Analisis kelayakan non finansial mengkaji kelayakan usaha berdasarkan aspek pasar, aspek teknis, aspek manajemen, aspek hukum, aspek manfaat. Penjelasannya adalah sebagai berikut.

1. Analisis aspek pasar meneliti variabel berupa potensi permintaan pasar, harga jual produk, penawaran, strategi pemasaran yang tepat untuk memasarkan produk.

2. Analisis aspek teknis meneliti variabel kondisi fisik, teknologi, keterampilan, lokasi usaha pembuatan pupuk organik, dan proses pengolahan yang dilakukan, kebutuhan tenaga kerja, dan kebutuhan fasilitas.

3. Analisis aspek manajemen menilai kualitas dan kemampuan orang-orang yang akan menangani proyek. Variabel yang diteliti meliputi bentuk usaha dan struktur organisasi, serta job description.

4. Analisis aspek hukum meneliti variabel bentuk badan usaha, akta pendirian, dan izin dalam menjalankan usaha.

5. Analisis aspek manfaat meneliti seberapa besar manfaat usaha secara sosial ekonomi dan lingkungan bagi masyarakat sekitar.

9) Tahap kesembilan, dijalankan yaitu kegiatan untuk mulai menjalankan usaha pupuk organik dengan mempertimbangkan hasil studi kelayakan usaha.

\section{HASIL DAN PEMBAHASAN}

Hasil analisis pada setiap aspek dalam studi kelayakan usaha pupuk organik adalah sebagai berikut.

\section{1) Penentuan Ide atau Gagasan}

Gagasan usaha pembuatan pupuk organik muncul dari kesepakan pihak KWT Desa Nambaan Kabupaten Kediri yang mengelola pertanian organik terpadu "vita varm". Pembuatan pupuk organik secara mandiri sudah pernah dilakukan oleh kelompok tani ini dengan menggunakan bahan-bahan yang diperoleh dari lahan organik yang dimiliki. Pemanfaatan limbah industri pembuatan cincau hitam UD RSA Kota Kediri menjadi bahan baku pupuk 
organik dinilai akan menjadi usaha yang prospektif dan menguntungkan kedua belah pihak. Perjanjian kerjasama disusun sebagai dasar hukum pelaksanaan usaha kemitraan yang dijalankan. Pupuk organik yang dihasilkan adalah pupuk organik padat yang dikemas dalam ukuran $5 \mathrm{~kg}$. Lokasi pembuatan pupuk organik di lahan pertanian organik terpadu "vita varm" Kabupaten Kediri. Bahan baku dan bahan penolong diangkut menggunakan armada truk ke lokasi produksi setiap satu minggu sekali. Kebutuhan mesin-mesin produksi pupuk organik dipenuhi dengan cara menyewa selama 3 bulan setiap kali produksi. Dalam satu tahun kegiatan produksi pupuk, organik dilakukan selama 3 kali untuk memenuhi kebutuhan pupuk permusim tanam. Penyaluran pupuk organik di wilayah Kabupaten Kediri didistribusikan kepada kelompok tani dan penjual tanaman hias.

\section{2) Pertimbangan Alternatif}

Modal usaha bersumber dari modal sendiri berupa uang kas KWT Desa Nambaan dan investasi pemilik lahan pertanian organik "vita varm". UD RSA berperan sebagai supplier bahan baku berupa limbah cincau hitam. Tenaga kerja bagian produksi, pengayak dan pengemas diperoleh dari KWT Desa Nambaan sebanyak 8 orang. Tenaga ahli yang dilibatkan dalam produksi pupuk organik adalah pegawai penuluh lapangan (PPL) di Desa Nambaan, Tim Ahli Pertanian Organik dari Kampus Universitas Islam Kadiri (UNISKA) Kediri. Bentuk pupuk organik yang akan dihasilkan dapat berupa pupuk padat dan pupuk cair. Dalam penelitian ini, pupuk yang akan diproduksi dan dipasarkan adalah jenis pupuk padat karena mempertimbangkan sumber daya yang dimiliki. Teknik pembuatan produk organik menggunakan pedoman Standar Mutu Produksi berdasakan PP Nomor 70 Tahun 2011 tentang pupuk organik. Teknik pemasaran yang digunakan adalah teknik pemasaran terpadu (marketing mix). Bentuk usaha yang dijalankan adalah perseorangan.

\section{3) Tujuan Usaha}

Visi usaha pupuk organik adalah menghasilkan Pupuk Organik Padat (POP) yang ramah lingkungan. Misi usaha pupuk organik yaitu menghasilkan pupuk organik yang dapat memperbaiki tekstur dan struktur tanah, sifat fisik, kimia, dan biologi tanah, dan sebagai media tumbuh tanaman.

\section{4) Pengumpulan Data}

yaitu kegiatan mengelompokkan data baik data primer maupun data sekunder. Data primer yang diperoleh antara lain : 1) data permintaan pupuk organik di wilayah Kecamatan Ngasem Kabupaten Kediri, 2) data biaya investasi pembuatan pupuk organik. Data sekunder yang diperoleh yaitu data aspek pasar, data aspek teknis, data aspek manajemen, data aspek hukum, dan data aspek manfaat.

Berdasarkan data permintaan pupuk organik yang ada di Kecamatan Ngasem, jumlah total permintaan pupuk organik sebesar $9.000 \mathrm{~kg}$ per musim tanam, maka dapat disimpulkan bahwa potensi pasar pupuk organik yang berada di sekitar lokasi usaha sangat besar. Segmentasi pasar yang dipilih adalah kelompok tani yang ada di wilayah Kecamatan Ngasem. Pengembangan penjualan pupuk organik didistribusikan pada penjual pupuk dan masyarakat secara langsung. Estimasi pendapatan dan biaya perlu dilakukan untuk mengetahui besarnya pendapatan dan pengeluaran yang akan terjadi selama periode produksi. Kegiatan produksi pupuk organik dilakukan sebanyak tiga kali dalam satu tahun. Jumlah produksi pupuk organik dan estimasi pendapatan adalah sebagai berikut.

Tabel 2. Data Estimasi Harga dan Pendapatan Pupuk Organik

\begin{tabular}{|c|c|c|}
\hline Estimasi Pendapatan & Jumlah & Keterangan \\
\hline Harga pupuk organik $(\mathrm{P})$ & $5 \mathrm{~kg}$ & $\begin{array}{c}\text { Rp } 1000 \times 5= \\
\operatorname{Rp} 5000\end{array}$ \\
\hline Jumlah produksi (Q) & $\begin{array}{c}9.000 \\
\mathrm{~kg}\end{array}$ & Per 4 bulan \\
\hline $\begin{array}{l}\text { Penerimaan per periode } \\
\text { produksi ( } 4 \text { bulan) }\end{array}$ & $P \times Q$ & $\begin{array}{c}\text { Rp } 5000 \mathrm{x} \\
9.000 \mathrm{~kg}= \\
\operatorname{Rp} 45.000 .000\end{array}$ \\
\hline Penerimaan per tahun & \multicolumn{2}{|c|}{$\begin{array}{c}\mathrm{Rp} 45.000 .000 \times 3 \text { periode } \\
\text { produksi }= \\
\operatorname{Rp} 135.000 .000\end{array}$} \\
\hline
\end{tabular}

Sumber : Data Olahan Keuangan Mitra 
Biaya kebutuhan investasi usaha pupuk organik adalah sebagai berikut.

Tabel 3. Data biaya investasi pembuatan pupuk organik

\begin{tabular}{|c|l|c|}
\hline No & Kebutuhan Investasi & Jumlah $(\mathrm{Rp})$ \\
\hline 1 & Sewa lahan & 1.250 .000 \\
\hline 2 & Bangunan atap lahan & 3.000 .000 \\
\hline 3 & Sarana dan perlengkapan & 1.000 .000 \\
\hline 4 & Sewa mesin & 1.400 .000 \\
\hline 5 & Peralatan & 1.881 .000 \\
\hline 6 & ongkos tenaga kerja & 1.050 .000 \\
\hline \multicolumn{2}{|c|}{ Jumlah kebutuhan investasi } & 9.681 .000 \\
\hline
\end{tabular}

Sumber : Data Olahan Keuangan Mitra

Biaya Kebutuhan Investasi bersumber dari dana sendiri yang digunakan untuk membeli atau menyewa aktiva yang dibutuhkan perusahaan mulai dari pendirian hingga dapat dioperasikan. Biaya yang disajikan merupakan estimasi pengeluaran yang perlu dipersiapkan wirausaha selama 4 bulan atau dalam satu periode produksi.

\section{5) Analisis Data}

Analisis usaha pupuk organik secara finansial bertujuan untuk menilai apakah investasi ini layak atau tidak layak untuk dijalankan dilihat dari aspek keuangan. Berdasarkan kegiatan pengumpulan data maka dirumuskan studi kasus proyek investasi usaha pupuk organik sebagai berikut. KWT Desa Nambaan menginvestasikan lahan seluas $10 \mathrm{ru}$ sebagai lokasi produksi pupuk organik senilai Rp 100.000.000,-. Total biaya yang dikeluarkan selama satu tahun sebesar Rp 9.681.000,-.x 3 periode $=\mathrm{Rp}$ 29.043.000,-. Umur ekonomis adalah 5 tahun. Penyusutan menggunakan metode garis lurus tanpa nilai sisa (residu). Pengembalian tingkat bunga yang diinginkan (cost of capital) adalah 20\%. Perkiraan pendapatan per tahun sebesar Rp 45.000.000,-. Pajak usaha sebesar 0,5\% per tahun.
Tabel 4. Cash flow selama Umur Ekonomis

\begin{tabular}{|c|c|c|c|c|c|}
\hline $\begin{array}{c}\text { Tahu } \\
\mathrm{n}\end{array}$ & EAT & $\begin{array}{c}\text { Penyu } \\
\text { sutan }\end{array}$ & Procced & $\begin{array}{c}\text { DF } \\
(20 \% \\
)\end{array}$ & $\begin{array}{c}\text { PV. } \\
\text { Kas } \\
\text { Bersih }\end{array}$ \\
\hline 2018 & $\begin{array}{c}858570 \\
00\end{array}$ & $\begin{array}{c}14191 \\
400\end{array}$ & $\begin{array}{c}100048 \\
400\end{array}$ & 0.83 & 830401 \\
& 852 \\
\hline 2019 & $\begin{array}{c}858570 \\
00\end{array}$ & $\begin{array}{c}14191 \\
400\end{array}$ & $\begin{array}{c}160920 \\
00\end{array}$ & 0.69 & $\begin{array}{c}111034 \\
80\end{array}$ \\
\hline 2020 & 858570 & 14191 & 169920 & 0.57 & $\begin{array}{c}968544 \\
0\end{array}$ \\
& 00 & 400 & 00 & & 849216 \\
2021 & 858570 & 14191 & 176920 & 0.48 & 0 \\
& 00 & 400 & 00 & & 727680 \\
2022 & 858570 & 14191 & 181920 & 0.4 & 0 \\
& 00 & 400 & 00 & & 501978 \\
& 429285 & 70957 & 169016 & & 708 \\
\hline
\end{tabular}

Sumber : Data diolah

Keterangan :

- EAT (earning after tax) = Laba setelah pajak

- Penyusutan = investasi : umur ekonomis

- Kas bersih $($ proceed $)=\mathrm{EAT}+$ penyusutan

- $\mathrm{DF}$ (discount factor $)=20 \%$

- $\mathrm{PVKB}=$ present value $\mathrm{kas}$ bersih

$$
\begin{aligned}
\text { Penyusutan } & =\frac{\text { Investasi }}{\text { Umur Ekonomis }} \\
& =\frac{100.000 .000}{5 \text { tahun }}
\end{aligned}
$$$$
=\text { Rp. } 20.000 .000
$$

\section{Estimasi laporan laba/rugi :}

Pendapatan

Rp 135.000.000

Biaya yang keluar

Total biaya $\mathrm{Rp} 29.043 .000$

Penyusutan Rp 20.000.00

Rp 49.043.000

Laba sebelum pajak (EBT)

Rp 85.957.000

Pajak 0,5\% (penyusutan)

Rp $\quad 100.000$

Laba setelah pajak (EAT)

Rp 85.857 .000

1. Perhitungan nilai bersih sekarang (Net Present Value/NPV)

NPV adalah selisih uang yang diterima dan uang yang dikeluarkan dengan 
memperhitungkan time value of money yaitu membandingkan berapakah nilai uang yang diterima saat ini dengan nilai uang yang diterima dimasa depan. Kriteria kelayakan investasi berdasarkan NPV adalah sebagai berikut.

- NPV >0, artinya usaha tersebut menguntungkan dan dapat dilaksanakan.

- $\quad \mathrm{NPV}<0$, artinya usaha tersebut merugikan dan sebaiknya tidak dilaksanakan.

- $\quad \mathrm{NPV}=0$, artinya usaha tersebut tidak untung dan tidak rugi.

Rumus menghitung NPV usaha pupuk organik adalah sebagai berikut.

$\mathrm{NPV}=$ Total PV kas bersih + Total PV kas investasi

$\mathrm{NPV}=$ Rp. $501.978 .708-$ Rp. $100.000 .000=$ Rp. 401.978 .708

Berdasarkan perhitungan yang dilakukan, NPV memiliki nilai positif atau NPV >0, maka usaha pupuk organik dinilai menguntungkan dan investasi usaha bisa dilaksanakan.

2. Perhitungan Rasio B/C (Net benefit and Cost Ratio)

Perhitungan Net B/C Ratio digunakan rumus $\mathrm{B} / \mathrm{C}$ rasio dengan membandingkan antara keuntungan dan biaya yang dikeluarkan. Adapun keuntungan usaha pupuk organik diperoleh dari selisih antara penerimaan dan total biaya.

Keuntungan $=$ Penerimaan - total biaya

Keuntungan per periode produksi (4 bulan) $=$ $\operatorname{Rp} 45.000 .000-\operatorname{Rp} 9.681 .000=\operatorname{Rp} 35.319 .000$

Keuntungan per tahun $=$ Rp. 135.000.000 - Rp. 29.043.000 = Rp 105.957.000

Kriteria perhitungan rasio $\mathrm{B} / \mathrm{C}$ adalah sebagai berikut.

- $\mathrm{B} / \mathrm{C}>1=$ Layak

- $\mathrm{B} / \mathrm{C} \leq 1$ = Tidak Layak

Berdasarkan perhitungan yang dilakukan, rasio $\mathrm{B} / \mathrm{C}$ memiliki nilai > 1, maka usaha pupuk organik dinilai layak untuk dilaksanakan karena setiap satu rupiah biaya yang dikeluarkan akan menghasilkan keuntungan lebih besar dari satu rupiah.

3. Perhitungan masa pengembalian investasi (Payback Period)

Metode payback period (PP) merupakan teknik penilaian terhadap jangka waktu (periode) pengembalian investasi suatu proyek atau usaha. Perhitungan PP usaha pupuk organik memperhitungkan kas bersih yang diperoleh setiap tahun. Diasumsikan nilai kas bersih yang diperoleh setiap tahun adalah sama. Rumus yang digunakan adalah sebagai berikut,

$\mathrm{PP}=\frac{\text { Investasi }}{\text { Kas bersih } / \text { tahun }} \times 1$ tahun

$\mathrm{PP}=\frac{100.000 .000}{85.857 .000} \times 12$ bulan $=13,98$ bulan $(14$ bulan atau 1 tahun 2 bulan)

Berdasarkan perhitungan PP, diketahui bahwa jangka waktu pengembalian investasi usaha pupuk organik adalah 1 tahun 2 bulan. Hal ini menunjukkan bahwa proyek investasi ini akan banyak disukai oleh para investor karena memiliki jangka waktu pengembalian investasi yang cukup pendek.

Analisis usaha pupuk organik secara non finansial bertujuan untuk menilai apakah investasi ini layak atau tidak layak untuk dijalankan dilihat dari aspek pasar, aspek teknis, aspek manajemen, aspek hukum, dan aspek manfaat. Pembahasan masing-masing aspek adalah sebagai berikut.

1. Analisis aspek pasar

Analisis aspek pasar bertujuan untuk mengetahui prospek pasar dan pemasaran usaha pupuk organik. Penjualan pupuk organik di Kecamatan ngasem sangat prospektif karena adanya permintaan pasar yang cukup besar setiap musim tanam. Segmen pasar yang ada diantaranya kelompok tani, penjual pupuk, konsumen langsung. Pasar potensial segmen kelompok tani yang menjadi target penjualan POP adalah sebagai berikut. 
Tabel 5. Segmentasi Pasar POP di Kecamatan Ngasem Kabupaten Kediri Tahun 2018

\begin{tabular}{|c|l|c|}
\hline No & \multicolumn{1}{|c|}{ Kelompok Tani } & $\begin{array}{c}\text { Permitaan Pupuk } \\
\text { Organik }\end{array}$ \\
\hline 1 & Tani Makmur I & $1.000 \mathrm{~kg}$ \\
\hline 2 & Tani Makmur II & $1.000 \mathrm{~kg}$ \\
\hline 3 & Tani Makmur III & $1.000 \mathrm{~kg}$ \\
\hline 4 & Tani Maju I & $1.000 \mathrm{~kg}$ \\
\hline 5 & Tani Maju II & $800 \mathrm{~kg}$ \\
\hline 6 & Ratih I & $900 \mathrm{~kg}$ \\
\hline 7 & Ratih II & $800 \mathrm{~kg}$ \\
\hline 8 & Waringin I & $800 \mathrm{~kg}$ \\
\hline 9 & Vita Varm & $700 \mathrm{~kg}$ \\
\hline 10 & Mugi Rahayu & $1.000 \mathrm{~kg}$ \\
\hline & Total permintaan & $9.000 \mathrm{~kg}$ \\
\hline
\end{tabular}

Sumber : Dinas Pertanian dan Perkebunan Kabupaten Kediri Tahun 2018

Kapasitas produksi POP dalam satu periode digunakan untuk memenuhi kebutuhan segmen kelompok tani di wilayah Ngasem. Apabila estimasi pasar sasaran tidak sesuai dengan rencana maka POP disalurkan pada segmen lain yang membutuhkan.

Strategi bauran pemasaran (marketing mix) POP terdiri dari strategi produk, strategi harga, strategi lokasi dan distribusi, strategi promosi. Strategi produk diantaranya membuat desain logo dan moto yang baik, menciptakan merek (nama) pupuk organik yang mudah diingat dan menarik perhatian, mendesain kemasan yang menarik, dan mendesain label produk. Strategi harga menggunakan standar harga pasar dengan ukuran kemasan $5 \mathrm{~kg}$ dijual dengan harga $\mathrm{Rp}$. 5.000,-. Strategi lokasi dan distribusi mempertimbangkan prinsip efisiensi dan efektifitas usaha. Lokasi usaha yang menjadi tempat produksi adalah lahan pribadi salah satu KWT Desa Nambaan yang mengelola pertanian organik terpadu "vita varm". Saluran distribusi pupuk organik dari produsen dijual secara langsung kepada konsumen. Strategi promosi menggunakan empat macam sarana promosi yaitu periklanan (advertising), promosi penjualan (sales promotion), penjualan pribadi (personal selling). Promosi melalui iklan dilakukan dengan cara memasang spanduk di lokasi usaha pembuatan POP, pemasangan iklan di media sosial facebook. Promosi penjualan dilakukan dengan cara memberikan harga khusus dan potongan harga kepada konsumen yang loyal. Penjualan pribadi dilakukan dengan bantuan tenaga penjualan secara personal.

\section{Analisis aspek teknis}

Analisis aspek teknis atau produksi bertujuan untuk menilai kesiapan pengelola dalam menjalankan usaha dengan menilai ketepatan lokasi, luas produksi, layout produksi, kesiagaan mesin-mesin yang akan digunakan. Lokasi produksi pupuk organik dipilih dengan pertimbangan kedekatan dengan pasar dan konsumen. Kapasitas produksi masih relatif sedikit dan hanya dapat memenuhi kebutuhan konsumen di sekitar wilayah Kecamatan Ngasem. Kondisi fisik POP yang dihasilkan telah dilakukan uji lab dan penilaian kelayakan mutu produksi oleh lembaga professional.

teknologi, keterampilan, lokasi usaha pembuatan pupuk organik, dan proses pengolahan yang dilakukan, kebutuhan tenaga kerja, dan kebutuhan fasilitas.

\section{Analisis Aspek Manajemen}

Analisis aspek manajemen bertujuan untuk mengkaji penerapan fungsi-fungsi manajemen yaitu perencanaan (planning), pengorganisasian (organizing), pelaksanaan (actuating), pengawasan (controlling) dalam mencapai tujuan usaha. Manajemen dikatakan efektif jika setiap fungsi berjalan secara baik dan benar dalam sebuah organisasi usaha. Sebelum usaha dijalankan, KWT Desa Nambaan menyusun tiga jenis perencanaan yaitu perencanaan organisasi, perencanaan produksi, dan perencanaan sumber daya manusia (SDM). Bentuk usaha yang akan dijalankan berupa usaha dagang (UD) dengan struktur organisasi yang masih sederhana. Analisis kebutuhan SDM dilakukan untuk mengetahui jumlah tenaga kerja yang dibutuhkan sesuai dengan aktivitas usaha. Selain itu, untuk menilai kualitas dan kemampuan orang-orang yang akan menangani usaha. Adapun aktivitas usaha yang dilakukan meliputi produksi, pemasaran, keuangan, personalia dan umum. Setiap aktivitas usaha memiliki pembagian tugas (pengorganisasian) yang jelas 
diikuti dengan kegiatan pengawasan. Manajemen usaha POP dapat dilihat dalam tabel berikut ini.

Tabel 6. Manajemen Usaha POP

\begin{tabular}{|c|c|c|}
\hline No & $\begin{array}{l}\text { Aktivitas } \\
\text { Usaha } \\
\text { POP }\end{array}$ & Pembagian tugas \\
\hline 1 & Produksi & $\begin{array}{ll}\text { - } & \text { Perencanaan produksi } \\
\text { - } & \text { Pencampuran bahan dan } \\
& \text { fermentasi } \\
\text { - } & \text { Pengayakan } \\
\text { - } & \text { Penimbangan } \\
\text { - } & \text { pengemasan } \\
\end{array}$ \\
\hline 2 & Pemasaran & $\begin{array}{ll}\text { - } & \text { Penjualan } \\
\text { - } & \text { Promosi }\end{array}$ \\
\hline 3 & Keuangan & $\begin{array}{ll}\text { - } & \text { Pengelolaan akuntansi } \\
\text { - } & \text { Manajemen harga produk } \\
\text { - } & \text { Manajemen gaji } \\
\end{array}$ \\
\hline 4 & $\begin{array}{l}\text { Personalia } \\
\text { dan umum }\end{array}$ & $\begin{array}{ll}\text { - } & \text { Administrasi tenaga kerja } \\
\text { - } & \text { Pelatihan dan } \\
\text { pengembangan karyawan } \\
\text { - Keamanan }\end{array}$ \\
\hline
\end{tabular}

Sumber : Data diolah

\section{Analisis Aspek Hukum}

Analisis aspek hukum bermanfaat untuk mengkaji bentuk badan usaha, akta pendirian, dan perizinan usaha. Bentuk badan usaha yang direncanakan adalah Badan usaha perseorangan dengan sistem kemitraan bersama KWT Desa Nambaan. Keabsahan dokumen usaha yang dikaji antara lain identitas pemilik usaha POP, status hukum tanah yang diinvestasikan untuk lokasi produksi POP, surat atau sertifikat yang diperlukan untuk kegiatan pengelolaan usaha POP. Perizinan usaha yang akan diproses yaitu tanda daftar perusahaan (TDP), surat izin usaha perdagangan (SIUP), dan nomor pokok wajib pajak (NPWP). Peneliti melakukan survey ke lapangan untuk mengecek kebenaran dari datadata dalam aspek hukum.

\section{Analisis Aspek Manfaat}

Analisis aspek manfaat bertujuan untuk mengkaji manfaat usaha secara ekonomi, sosial, dan lingkungan bagi seluruh masyarakat. Setiap usaha yang muncul di lingkungan masyarakat akan membawa dampak positif dan negatif bagi pemangku kepentingan dan masyarakat luas. Rencana usaha POP ini memberikan dampak positif secara ekonomi bagi UD RSA, calon investor, dan pemerintah. Bagi UD RSA, dengan munculnya usaha POP yang menggunakan bahan baku limbah produksi cincau hitam, maka manajer UD RSA dapat menghemat biaya angkut dan pembuangan limbah industri ke TPA. Calon investor dari kalangan masyarakat dapat menanamkan modalnya kepada pihak manajemen usaha POP dan menikmati keuntungan dari hasil investasi yang dilakukan. Pemerintah akan memiliki pemasukan dari sektor pajak usaha yang telah disetorkan oleh wajib pajak. Secara ekonomi dampak negatif yang muncul dengan adanya usaha POP adalah bertambahnya jumlah produsen pupuk organik sehingga jumlah pesaing usaha sejenis semakin besar.

Dampak positif dari aspek sosial pendirian usaha POP dapat dinikmati oleh KWT Desa Nambaan dan kelompok tani di wilayah Ngasem Kabupaten Kediri. Kebutuhan POP setiap musim tanam akan mudah terpenuhi. Pembuatan pupuk organik secara mandiri sekaligus dapat meningkatkan kualitas pendidikan dan keterampilan seluruh anggota KWT Desa Nambaan dalam menghasilkan produk POP yang ramah lingkungan. Dampak negatif dari aspek sosial akan dirasakan oleh anggota kelompok tani yang belum terbiasa membuat pupuk organik secara mandiri akhirnya dituntut untuk belajar, hal ini akan merubah budaya lama menjadi budaya baru.

Dampak positif dari aspek lingkungan masyarakat dengan adanya usaha POP yaitu adanya kegiatan masyarakat dalam mengelola limbah menjadi barang baru yang memiliki nilai ekonomi tinggi dan lebih bermanfaat bagi masyarakat yang mengelola pertanian organik. Usaha POP akan dapat membuka kesempatan kerja bagi kelompok tani dan kelompok masyarakat yang bergabung menjadi tenaga kerja dalam usaha tersebut. Usaha POP yang akan didirikan dapat menjadi wahana masyarakat untuk melakukan studi banding dan meningkatkan pengalaman lapangan dalam melakukan proses produksi POP. Dampak negatif usaha POP hamper tidak ada karena dipastikan produk yang dihasilkan tidak akan 
merusak lingkungan, tetapi akan memperbaiki kesuburan tanah dan menjaga kualitas hasil alam berupa makanan organik.

\section{6) Keputusan}

Berdasarkan analisis data yang telah dilakukan dan membandingkan hasil analisis dengan kriteria kelayakan, usaha pupuk organik layak dijalankan secara finansial maupun non finansial. Kesimpulan kelayakan aspek finansial usaha POP adalah sebagai berikut.

Tabel 7. Kesimpulan Analisis Kelayakan Usaha POP berdasarkan aspek finansial

\begin{tabular}{|c|c|c|c|c|}
\hline No & $\begin{array}{c}\text { Alat } \\
\text { Ukur }\end{array}$ & $\begin{array}{c}\text { Hasil } \\
\text { Pengukuran }\end{array}$ & $\begin{array}{c}\text { Kriteria } \\
\text { kelayakan }\end{array}$ & Keterangan \\
\hline 1 & NPV & $\begin{array}{c}\text { Rp. } \\
401.978 .708\end{array}$ & NPV $>0$ & Layak \\
\hline 2 & $\begin{array}{c}\text { Rasio } \\
\text { B/C }\end{array}$ & $\begin{array}{c}\text { Rp } \\
105.957 .000\end{array}$ & B/C > 1 & Layak \\
\hline 3 & PP & $\begin{array}{c}1 \text { tahun 2 } \\
\text { bulan }\end{array}$ & $\begin{array}{c}\text { Jangka } \\
\text { waktu } \\
\text { pendek }\end{array}$ & Layak \\
\hline
\end{tabular}

Sumber : Data diolah

Kesimpulan kelayakan aspek non finansial usaha POP adalah sebagai berikut.

Tabel 8. Kesimpulan Analisis Kelayakan Usaha POP

\begin{tabular}{|c|c|c|c|c|}
\hline No & Alat Ukur & $\begin{array}{c}\text { Hasil } \\
\text { pengukuran }\end{array}$ & $\begin{array}{c}\text { Sumber } \\
\text { data }\end{array}$ & $\begin{array}{c}\text { Ketera- } \\
\text { ngan }\end{array}$ \\
\hline 1 & $\begin{array}{c}\text { Aspek } \\
\text { Pasar }\end{array}$ & $\begin{array}{c}\text { Data } \\
\text { kuantitatif }\end{array}$ & $\begin{array}{c}\text { RDKK, } \\
\text { Poktan dan } \\
\text { Gapoktan, } \\
\text { LMDH }\end{array}$ & $\begin{array}{c}\text { Peluang } \\
\text { besar }\end{array}$ \\
\hline 2 & $\begin{array}{c}\text { Aspek } \\
\text { Teknis }\end{array}$ & $\begin{array}{c}\text { Data } \\
\text { kualitatif }\end{array}$ & $\begin{array}{c}\text { PPL, } \\
\text { Tenaga } \\
\text { Ahli }\end{array}$ & $\begin{array}{c}\text { Prosesnya } \\
\text { aplikatif }\end{array}$ \\
\hline 3 & $\begin{array}{c}\text { Aspek } \\
\text { Manajemen }\end{array}$ & $\begin{array}{c}\text { Data } \\
\text { kualitatif }\end{array}$ & $\begin{array}{c}\text { Manajemen } \\
\text { Usaha POP }\end{array}$ & Jelas \\
\hline 4 & $\begin{array}{c}\text { Aspek } \\
\text { Hukum }\end{array}$ & $\begin{array}{c}\text { Data } \\
\text { kualitatif }\end{array}$ & $\begin{array}{c}\text { Manajemen } \\
\text { Usaha POP }\end{array}$ & Legal \\
\hline 5 & $\begin{array}{c}\text { Aspek } \\
\text { Manfaat }\end{array}$ & $\begin{array}{c}\text { Data } \\
\text { kualitatif }\end{array}$ & $\begin{array}{c}\text { Manajemen } \\
\text { Usaha POP }\end{array}$ & $\begin{array}{c}\text { Layak dan } \\
\text { bermanfaat }\end{array}$ \\
\hline
\end{tabular}

Sumber : data diolah

\section{7) Rekomendasi}

Usaha pembuatan pupuk organik layak untuk dijalankan karena dapat memberikan keuntungan bagi pihak UD RSA maupun pihak KWT Desa Nambaan berdasarkan analisis finansial dan non finansial. Keuntungan yang dapat diperoleh dari adanya kerjasama kemitraan usaha pupuk organik diantaranya sebagai berikut.

- UD RSA tidak perlu membuang limbah cincau ke TPA (tempat pembuangan sampah akhir) Kota Kediri, karena limbah organik dapat dimanfaatkan sebagai bahan baku pembuatan pupuk organik.

- UD RSA bisa berpartisipasi menjadi investor usaha pupuk organik, sehingga dapat memperoleh keuntungan investasi dalam jangka waktu pengembalian yang cukup pendek.

- KWT Desa Nambaan dapat mengembangkan kemampuan dan keterampilan dalam memproduksi pupuk organik secara mandiri, sehingga dapat menghemat biaya pembelian pupuk organik untuk memenuhi kebutuhan pertanian organik yang dikelola.

- KWT Desa Nambaan dapat penjadi produsen pupuk organik yang dipasarkan secara luas kepada masyarakat dengan membentuk usaha dagang (UD). Hal ini dapat memberikan manfaat seluas - luasnya baik secara sosial, ekonomi, maupun lingkungan.

\section{KESIMPULAN}

Hasil analisis studi kelayakan usaha pupuk organik ini dapat digunakan oleh kedua mitra usaha yaitu UD RSA dan KWT Desa Nambaan sebagai dasar pengambilan keputusan investasi. Berdasarkan aspek finansial usaha ini dinilai layak untuk dilaksanakan karena memiliki resiko kerugian yang kecil dan jangka waktu pengembalian investasi yang relatif pendek. Berdasarkan aspek non finansial, usaha ini memiliki peluang pasar yang besar dan telah memenuhi standar administatif berdasarkan aspek pasar, produksi, manajemen, hukum dan manfaat. Hasil penelitian ini diharapkan dapat memberikan masukan kepada investor dalam mengambil keputusan untuk menanamkan modalnya dalam usaha ini. 
Saran yang dapat kami sampaikan adalah bahwa analisis kelayakan usaha POP ini masih sangat sederhana sehingga perlu adanya penyempurnaan. Pada aspek finansial, metode yang digunakan untuk mengukur kelayakan usaha dapat dikembangkan apabila modal usaha diperluas sumbernya seperti mendapatkan pinjaman dari bank atau investasi berjangka dari pihak investor. Metode lain yang dapat digunakan antara lain perhitungan ARR (average rate of return), IRR (internal rate of return), rasio keuangan diantaranya rasio likuiditas, solvabilitas, aktivitas, dan profitabilitas.

Aspek pasar yang dikaji belum secara detail mendeskripsikan proses riset pasar dan analisis pesaing usaha pupuk organik di wilayah Kediri. Untuk menghasilkan analisis kelayakan usaha yang lebih rinci, diperlukan studi berbagai aspek finansial dan aspek nonfinansial yang belum dikaji dalam artikel ini.

\section{DAFTAR PUSTAKA}

Jakfar, Kasmir. 2016. Studi Kelayakan Bisnis. Jakarta: PT Kharisma Putra Utama.

Jumingan. 2014. Studi Kelayakan Bisnis : Teori dan Pembuatan Proposal Kelayakan. Jakarta : Bumi Aksara.
Rendy, Ahmad Putra. 2010. Skripsi berjudul Analisis Kelayakan Usaha Pupuk Organik Darul Fallah (Studi Kasus : Unit Pupuk Organik Pondok Pesantren Darul Fallah, Kabupaten Bogor, Jawa Barat). Bogor : Departemen Agribisnis Fakultas Ekonomi Dan Manajemen Institut Pertanian Bogor.

Republika.co.id. 2017

Waris, Moh., Martono Achmar. Artikel berjudul Analisis Kelayakan Usaha Pupuk Organik Kelompok Tani Sumber Tani Desa Sumber Anyar Kecamatan Mlandingan Kabupaten Situbondo. Dosen Fakultas Pertanian Universitas Abdurachman Saleh.

Zulkarnaini, Afrizal, Yuniar, Alex Saleh. 2014. Artikel berjudul Analisis Kelayakan Pembangunan Usaha Pupuk Organik di Provinsi Lampung. Bandung : Reka Integra ISSN: 2338-5081 No.03 Vol.01 Jurnal Online Institut Teknologi Nasional (Itenas) bandung Jurusan Teknik Industri. 